REFLECTIONS:

NEUROLOGY AND

THE HUMANITIES

Section Editor

Anne W. McCammon,

MD, FAAN

Ellen D. Feld, MD

Correspondence to

Dr. Feld:

edf26@drexel.edu

\title{
Better you than me
}

In July 1984, during the second week of my internship, I picked up "Steven Ferris,"* and I disliked him immediately. This came as a surprise; in all the years leading up to physicianhood, I never imagined disliking patients, or even being angry with them. And I certainly had no inkling of the effect antipathy might have on my caregiving skills.

Back then, patients who had no private physician became "our" clinic patients; residents managed them with varying amounts of supervision, depending on the clinic attending.

While my name is not common, it is pronounced exactly as it's spelled. But I'd been asked to repeat it so often ("Did you say Fell? Seld? Felt?"), that, unwittingly, I'd adopted a slow, speaking-to-a-foreignerwho-is-hard-of-hearing way of pronouncing it ("Fellll-duh") when introducing myself to patients.

When I introduced myself to Steven Ferris, he grinned and, mimicking my speech, repeated: "Dr. Fellll-duh."

"Why did you repeat my name?" I asked, taken aback.

"You just said it so strangely," he replied, with an I've-got-your-number grin.

Ferris had been admitted that morning after "coding" in a podiatrist's office adjacent to the hospital. I've put "coded" in quotes because, technically, he hadn't. Yes, a code had been called, but Ferris had not suffered a cardiac or respiratory arrest. He had simply had a seizure. But it had been a violent seizure (falling on the floor, knocking things over), so the podiatrist's inexperienced medical assistant called a code, and the code team came running over from the hospital. They started an IV, administered Ativan, and the seizure eventually stopped.

Because this had been a prolonged seizure, and because Ferris's girlfriend said he'd recently had more seizures than usual, he was admitted to a medical floor and became my patient.

Ferris seemed more like an annoying teenager than a 20 -something. He and his girlfriend were arrogant and inseparable. The two them of claimed to know more about seizures (particularly his seizures) than the rest of us could ever hope to, and they spent most of their time eating candy, watching TV game shows, and laughing at private jokes.

These, however, were the least of my worries right then. His seizures were very difficult to control. He had at least one per day, and many nights he would have a whopper at around midnight. I was almost always the one who treated his seizures, as they usually occurred when I was on the floor or on call. They appeared to my inexperienced eyes to be typical tonicclonic seizures—lots of jerking and kicking (although never any incontinence or tongue-biting), followed by odd periods of unintelligible mumblings. I spent a lot of time administering Ativan and conferring with attending neurologists about which medications to try nexttime I could have spent with other patients, or sleeping, or getting out of the hospital before 9 PM.

While his arrogance set my teeth on edge, and his seizures chewed huge holes in my already moth-eaten work and sleep schedules, Ferris was an otherwise compliant and good-natured patient. He accepted every new antiseizure regimen and willingly endured a head CT, EEG, and lumbar puncture, all of which came back with normal results. No surprise there; he'd said he had an idiopathic seizure disorder, and nothing in his history or physical examination ever suggested otherwise.

Life with Ferris went something like this: a burst of seizures, followed by a new medication regimen; then the seizures would taper off for a day or two until we would finally have a completely seizure-free day, during which we all (residents, attendings, nurses) held our collective breaths. But, always, after about 24 hours, the seizures would start right back up, and the whole cycle would repeat.

We muddled along like this, and I began to despair of ever discharging him. Then one morning, late in the second week of his hospitalization, the unit clerk handed me a large envelope that had arrived in the mail. Inside I found records from an admission Ferris had had at a nearby hospital, for uncontrolled seizures, exactly 1 year earlier.

I had requested the records on the day of Ferris's admission, then I'd forgotten about them. We always requested old records from other hospitals, but, with

*Fictitious name.

Listen to Dr. Feld read this story, available exclusively on Neurology ${ }^{\circledR}$ for the iPad ${ }^{\circledR}$. 
typical resident hubris, we never really cared if they arrived: we knew as much or more than any residents elsewhere. If they hadn't done a lousy job with the patient, we reasoned, he wouldn't have landed on our doorstep sick enough to need admission.

Normally, I would have given the records a cursory glance and then shoved them in the back of Ferris's chart. But I had been on call the night before, and I was tired. So sitting down and flipping through records was actually appealing at that moment, and that is what I did.

The early part of his hospital course was almost identical to what we had just been through: multiple normal tests, multiple different medications, occasional seizure-free days, always followed by a new flurry of seizures and another medication adjustment. It was nowhere near interesting enough to keep me awake, so I flipped ahead to the punch line, the discharge summary.

Well, the discharge summary, especially the last paragraph, woke me right up: "Discharge diagnosis: (1) Probable Munchausen's syndrome. (2) Possible seizure disorder. (3) Drug-seeking behavior."

The resident's name and beeper number were on the page, and I called him right away. He laughed when he heard who I was calling about: "Ah, Mr. Ferris," he said. "Better you than me."

Then he outlined his experience the previous July: He had also picked up Ferris early in his residency and like me, he had never seen a seizure before. $\mathrm{He}$ had been more diligent than I in searching for old records, and he became suspicious when he found several previous admissions to nearby hospitals for seizure control, all in early July. His hospital, unlike mine, had an inpatient epilepsy unit with continuous EEG monitoring. They put Ferris in that unit for 72 hours. On their regular medical floor, as at my hospital, Ferris had never gone more than 24 hours without a seizure, but in the monitoring unit he did not seize once.

Very likely you figured Ferris out long before we did: Ferris did not have a seizure while hooked up to monitors because, if he had, the tracings would have revealed that these episodes were nothing more than well-rehearsed limb-flailing performances designed to elicit Ativan injections from inexperienced house staff.

They discharged Ferris, explaining to him that on subsequent hospitalizations he would be admitted directly to the EEG monitoring unit. They never saw him again.

Finally, it made sense: he had seized almost exclusively in front of me, never in front of an attending, and rarely in front of more experienced residents.
The one time a second-year resident witnessed a seizure, he briefly scratched his head and said something seemed strange. But he was more than happy to have me take charge, and did not always remember to follow up on non-life-threatening issues. I felt that I had been had, and I was furious. Shaking with anger, fatigue, and caffeine, I marched into his room. I told him that I'd spoken with his doctor from the other hospital and that I knew about his previous admissions. I ended my rant with something like, "This is the end of the line for you, buster. You're going home!"

Now, it happened to be my last day on that floor-I was headed for the intensive care unit and had written my off-service notes. The intern who was taking over my patients, a good friend, was on the floor going through charts. She had, in fact, overheard my phone conversation with the resident at the other hospital. I couldn't possibly, in good conscience, bequeath this most difficult of all patients to her. So I quickly completed his discharge paperwork, documenting what I had learned in the past hour in a voluminous progress note.

I was still fuming when I got home that night. But by the next morning I was so busy in the intensive care unit that it barely registered when the neurologist told me, in passing, that Ferris had seized in the hospital lobby on his way out the previous evening, and he was now back on my old floor. He chided me for discharging Ferris so hastily —in my anger I'd neglected to arrange any type of follow-up, or even to give him prescriptions for antiseizure medications-a serious omission. While most of his "seizures" in the hospital were performances for our benefit, he probably did have an underlying seizure disorder that, however mild, had been what launched his charade.

Seeing my fellow intern at afternoon conference that day filled me with remorse, and I immediately launched into an apology.

"I can't believe I sent him home on no meds, with no follow-up," I began. "I was just so angry after I learned that I'd been duped!" She interrupted when I stopped for breath.

"Not to worry," she said. "He's gone."

"What?" I sputtered in disbelief. "How?" I wondered, briefly, whether she'd somehow managed to kill him.

"Well, I immediately got rid of all of his candy and outside food, and I put him on a strict ketogenic diet. I also did away with his television because I couldn't risk the photic stimulation causing more seizures. And I ordered a psych consult." She smiled. "He signed himself out against medical advice an hour ago." 


\title{
Neurology
}

\author{
Better you than me \\ Ellen D. Feld \\ Neurology 2015;84;1607-1608 \\ DOI 10.1212/WNL.0000000000001479
}

\section{This information is current as of April 13, 2015}

\section{Updated Information \&} Services

\section{Subspecialty Collections}

\section{Permissions \& Licensing}

Reprints including high resolution figures, can be found at: http://n.neurology.org/content/84/15/1607.full

This article, along with others on similar topics, appears in the following collection(s):

\section{All Clinical Neurology}

http://n.neurology.org/cgi/collection/all_clinical_neurology

\section{Malingering}

http://n.neurology.org/cgi/collection/malingering

MRI

http://n.neurology.org/cgi/collection/mri

Information about reproducing this article in parts (figures,tables) or in its entirety can be found online at:

http://www.neurology.org/about/about_the_journal\#permissions

Information about ordering reprints can be found online: http://n.neurology.org/subscribers/advertise

Neurology ${ }^{\circledR}$ is the official journal of the American Academy of Neurology. Published continuously since 1951, it is now a weekly with 48 issues per year. Copyright @ 2015 American Academy of Neurology. All rights reserved. Print ISSN: 0028-3878. Online ISSN: 1526-632X.

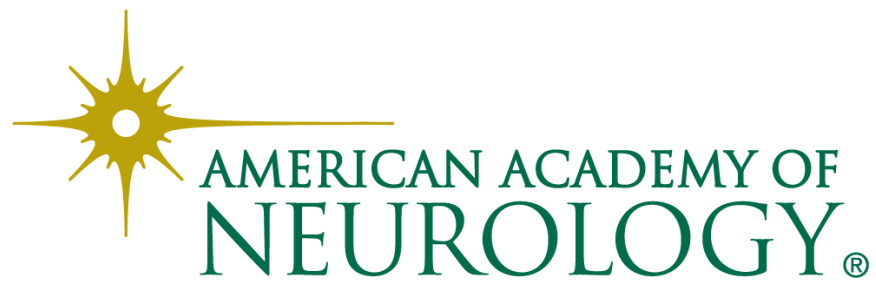

